\title{
Turn On Light Raspberry Pi To Reduce Traffic Jam
}

\author{
Ageng Setiani Rafika ${ }^{* 1}$, Hendra Kusumah ${ }^{2}$, Mayang Septiawati ${ }^{3}$ \\ 1,2,3 Fakultas Sains \& Technology University of Raharja \\ E-mail: ${ }^{* 1}$ agengsetianirafika@ raharja.info, ${ }^{2}$ hendra.kusumah@ raharja.info, \\ 3mayang.septiawati@raharja.info
}

\begin{abstract}
Nowadays human and computer communication has changed from time to time. The change is aimed at making communication between humans and computers more efficient. Human needs for information and communication are increasing with digital communication, the microcontroller used is Raspberry Pi 3. The traffic conditions are very congested, using a manual system does not work optimally due to the number of undisciplined road users and the increasing amount of volume vehicles every year. Therefore it is very necessary that the LEDs are turned on to reduce the volume density of the vehicle, especially at the intersection, and can control the time of the traffic lights in accordance with the specified time. Internet of Things (IoT) uses Raspberry Pi 3, ESP8266 Wi-fi Module, Sensor RCWL 0516 and Blynk. Raspberry Pi 3 as the main controller uses wireless networks, and makes devices able to communication such as sending and receiving data. The Blynk application is able to provide information in real time as well as remote control monitoring. When the sensor detects, the ESP8266 Wi-fi Module will send traffic density notifications via Smartphone so that it can provide information on road conditions periodically. The purpose of this study is to monitor the condition of the road from a distance so that road users are disciplined in driving and do not commit violations when the red light is on.
\end{abstract}

Keywords - Raspberry Pi, Traffic Led, Technology

\section{INTRODUCTION}

Traffic congestion is a problem that we often encounter, especially in big cities in Indonesia. Areas that often occur congestion such as at intersection of three or at intersection of four [1]. There is often congestion such as at intersection three or at intersection four [1]. Based on the years 2013 National Development Planning Agency (Bappenas) projection, the population of Indonesia in 2018 will reach 265 million [2]. Therefore the number of residents is directly proportional to the number of vehicles, so that if the population increases, it is certain that the vehicles will increase. Although the supporting facilities for motorists have been provided by the government, they have not functioned properly. Traffic conditions in Indonesia are very worrying, especially in Jakarta, the nation's capital. To represent how traffic conditions and all ethics are applied on the road, research is needed. Every day the addition of vehicle volumes in Jakarta increases significantly. In 2011 the number of motor vehicles in Indonesia reached 107,226,572 million, cars totaling 20,158,595 units and motorcycles $87,067,796$ units. The number is increasing every year [3]. 
Based on the problem of traffic congestion that occurs, overcoming it needs a tool that can help reduce congestion, especially at road intersections. Therefore Traffic Led is needed, by using Traffic Led will reduce traffic jams on the road. In Indonesia, one of the impacts of these technological developments is that road users are increasing and causing traffic congestion. Traffic violations are caused by undisciplined road users or passing Traffic Light when the red lamp light is on [4]. Then the function of the Led can be said that one of the most important instruments in smooth traffic lies in the ignition of the Led.

Currently, there have been many new tools or systems that have been successfully created, these tools or systems are very helpful for human work in life in society. So it was made a robot control system that can be controlled using a Smartphone [5]. With the existence of the Internet of Thing (IoT) system, it can monitor and control real-time traffic conditions [6]. One example of the development of IoT is the Raspberry Pi, which is connected to the Blynk application so that it creates a tool to determine the condition of the traffic lights periodically.

\section{RESEARCH METHOD}

In this study a literature reviews method of existing research, to find out differences with previous research. Much of the research previously done regarding Literature Review regarding the concept of using Internet of Things (IoT). In this study, a literature review method was carried out on existing research, to find out the difference with previous research. Many previous studies have been conducted on the Literature Review regarding the concept of using the Internet of Things (IoT).

The following are 10 (ten) literature reviews that researchers have quoted and their sources, including:

1) Research conducted by Ai Fitri Silvia, et al. from the Indonesian University of Education in 2014 the title is "Design of Arduino Uno and Android Based Gate Access Control" This study describes the monitoring and control of the gate with a Smartphone via Bluetooth HC-05 [7].

2) Research conducted by Dias Prihatmoko, from Nahdlatul Ulama University in Jepara in 201 with the title "Design and Implementation of Room Temperature Control Based on Arduino Uno Microcontroller" This research explains about controlling the temperature in the room using Arduino Uno microcontroller and displaying on LCD screen. [8]

3) Research conducted by Ratnawati from STMIK AKBA in 2017 with the title "Control System for Watering Plants Using Propeller Based on the Internet of Things" This research explains about producing prototypes in the form of watering plants automatically by detecting soil moisture levels [9].

4) Research conducted by Tatik Juwariyah, et al. from Faculty of Engineering of the Jakarta Veterans National Development University in 2018 with the title "Designing an ESP8266 and Blynk-Based Early Detection System for Home Fire Prevention" This study describes an Arduino-based early fire prevention system that is controlled through the online Blynk application using ESP8266 [10]. 
5) Research conducted by Derfian Mahardika Putra from the University of Jember in 2017 the title is "Prototype of Land Moisture Control and Monitoring System through Android-Based Local Blynk Server" This research explains about one of the features of the Blynk application, namely local server that can communicate with the network.[11].

6) Research conducted by Dewi Immaniar, et al. in 2014 from the University of Raharja the title is "Control System for Moving Goods Using an Android Application Based on Arduino Uno" This study describes a robot moving goods and can be controlled remotely [12].

7) Research conducted by Arif Azhari from the University of North Sumatra in 2015 the title is "Designing Arduino Uno-Based Water Discharge Information System" This research describes a prototype based technology system that is able to monitor the amount of water use [13].

8) Research conducted by Alfiah Khoirunisa from Raharja University in 2019 with the title is "Information Management Optimization Assignment Reports on a Content Management System Based Website" This study describes learning methods created to maximize and streamline time [14].

9) Research conducted by Oktorio Ari Pradana from Raharja University in 2019 the title "Smart Cars Design using Arduino-Based Uno Speech Recognition" This study describes the automatic car control system using voice commands via Smartphone [15].

10) Research conducted by Danny Kurnianto, et al from ST3 Telkom Purwokerto in 2016 with the title "Automatical Control System Design in Smart Home Using Arduino Uno Module" This study describes the Smart Home Model which is controlled centrally by an Arduino Uno microcontroller [16].

\section{RESEARCH RESULTS AND DISCUSSION}

\subsection{Design Prototype}

The prototype that has been made has 4 (four) capabilities including:

1) Access the application in real time remote monitoring from gadgets connected to the internet.

2) Detect if there is movement of objects around the sensor area;

3) There is an LED light display on the blynk application if the sensor reads a movement;

4) There is a notification object in the blynk application in real time;

The design of this tool consists of 2 (two) parts, namely hardware and software, consisting of 8 hardware devices and 1 (one) software including:

\section{A. Hardware}

The following is a block diagram of the hardware part shown in Picture 1. The design concept is to add a microcomputer component, a Wi-Fi module (ESP8266), power adapter, and a RWCL0516 sensor module. 


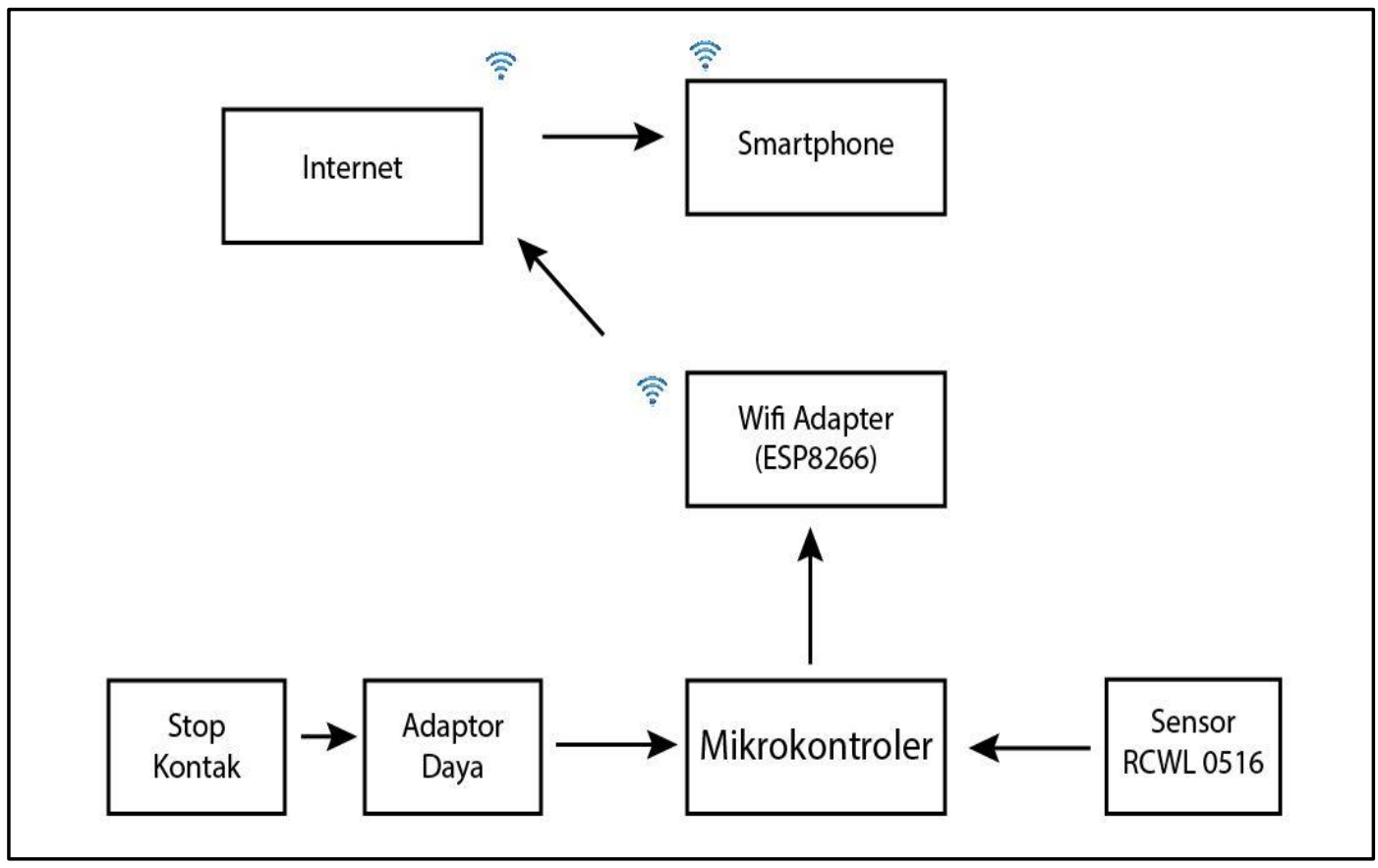

Picture 1. Tool Block Diagram

\section{Microcomputer}

Raspberry Pi 3 is a single-board circuit (SBC) the size of a credit card that can be used to run office programs, computer games, training models of Machine Learning and as a media player to high resolution video. The hardware has an ARM1176JZF-S processor with 700 $\mathrm{MHz}$, GPU Video-Core IV, and the software has its own programming language, namely the Python programming language.[17]

The reason why choose Raspberry Pi 3 is because the tool can do everything that a computer / laptop with a Linux operating system can do. For example, making a server, making programs with various languages, especially high-level languages like Python. Raspberry Pi as if replacing computer functions, but in the form of a mini. Raspberry Pi can be likened to a mini computer.[18].

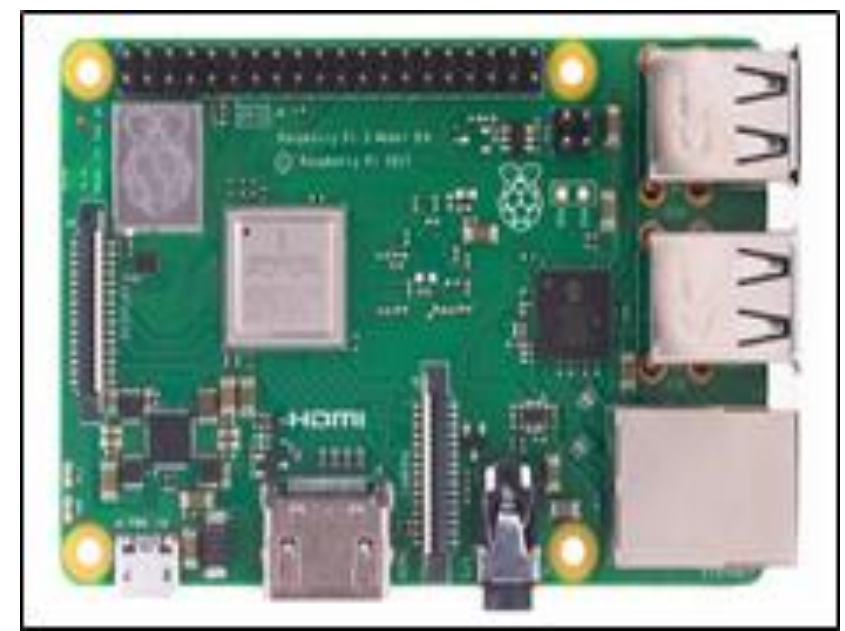

Picture 2. Raspberry Pi 3B 


\section{ESP8266 Wi-Fi Module}

Quoted from Wikipedia, The Esp8266 module is a Wi-Fi module that functions as a microcontroller or microprocessor enhancement tool such as Arduino and Raspberry Pi so that it can connect directly to Wi-Fi and make connections between devices and networks.[19].

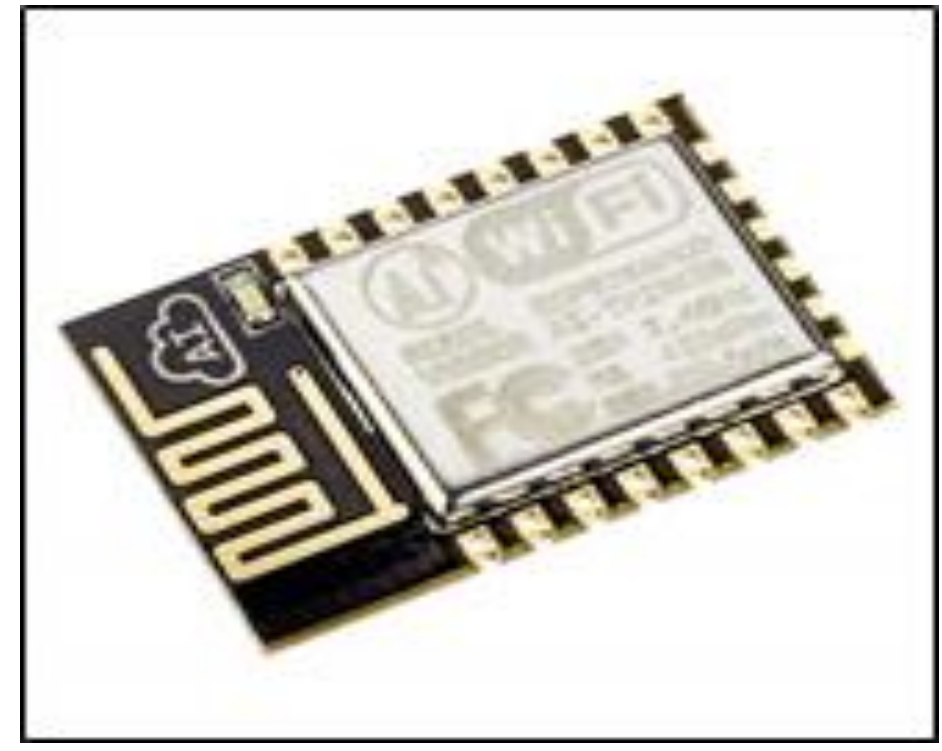

Picture 3. ESP8266 Wi-Fi Module

\section{Sensor RCWL 0516}

The RCWL 0516 module is a Doppler radar microwave motion sensor module, the tool works by reading the surrounding sound waves and this sensor can read movement up to a distance of 4 meters from the object towards the sensor.

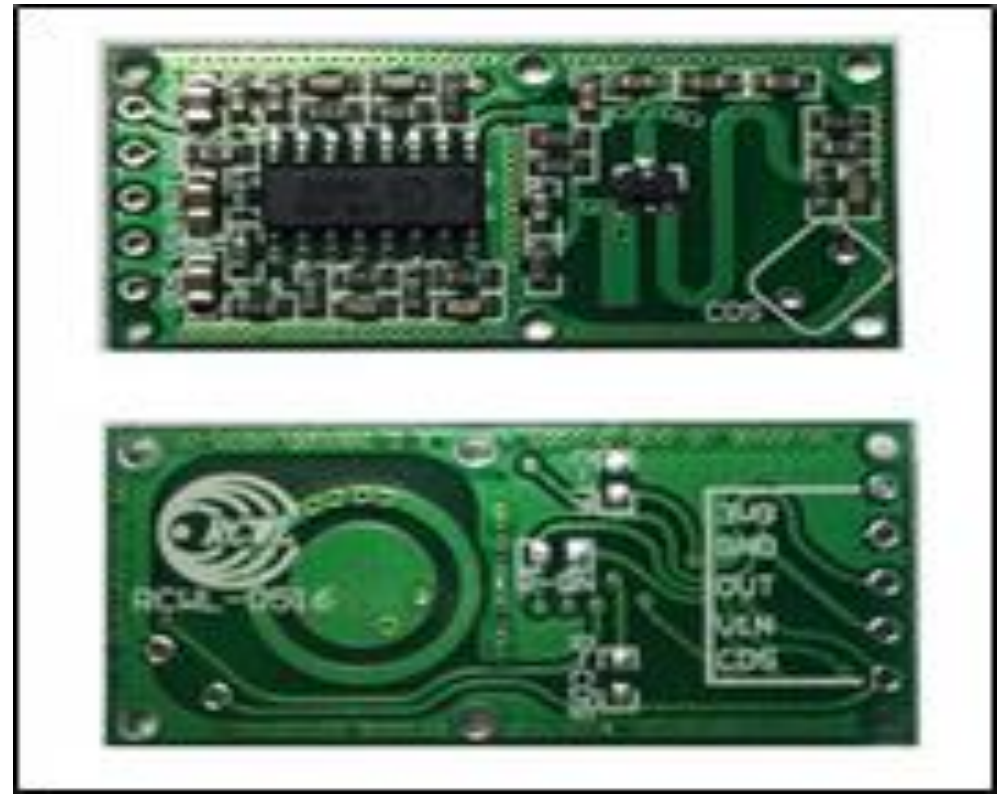

Picture 4. Sensor RCWL 0516 
a. Piece of Breadboard

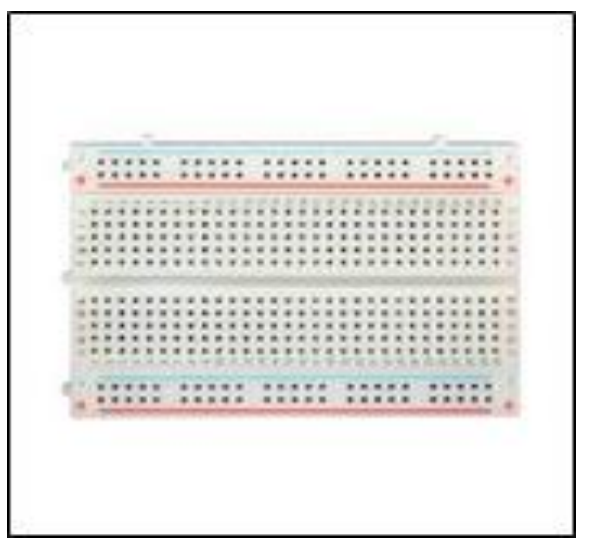

Picture 5. Breadboard

b. Female to Male Jumper Cables

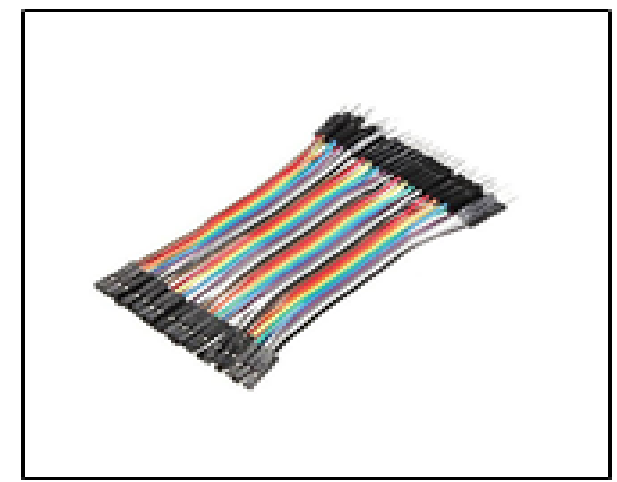

Picture 6. Female to Male Jumper Cables

c. LED of any color

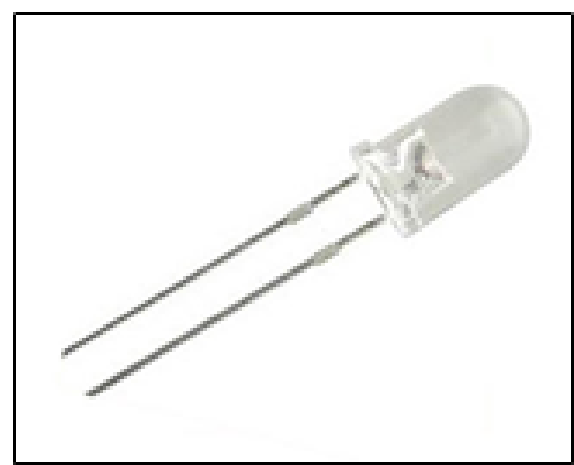

Picture 7. LED 


\section{d. $220 \mathrm{ohm}$ resistor}

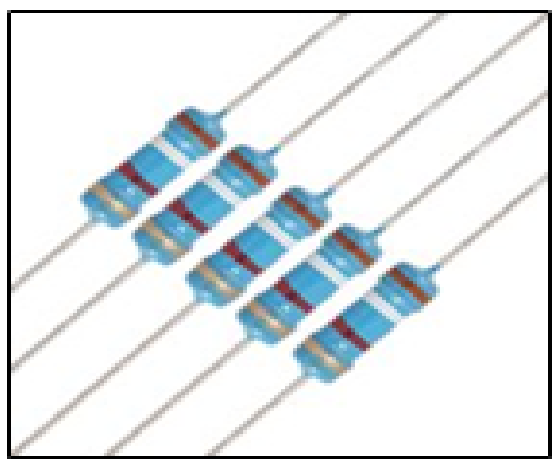

Picture 8. Resistor

\section{B. Software}

\section{Blynk Application}

Blynk is an IOS or Android based on application to control microcontrollers or microcomputer via the internet. The blynk application can help administrators monitor something practically. Blynk application was designed for the Internet of Things. It can control the hardware remotely. The application can use display sensor data, store data, visualize it and do many others.[20]

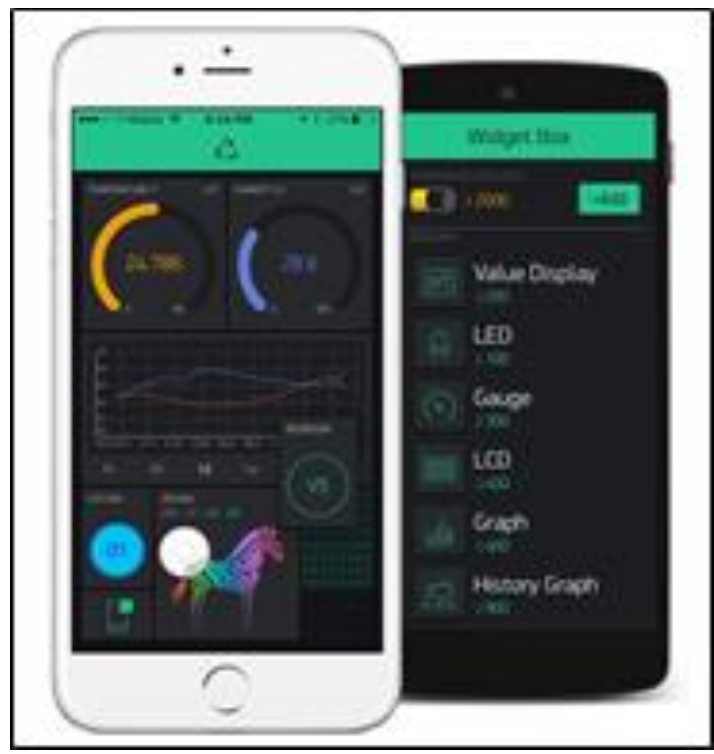

Picture 9. Display Blynk on gadgets

Blynk application program on the microcomputer chip using Raspberry Pi 3 which has been installed ESP8266 module, then the next steps:

1. First we turn on Raspberry Pi

2. After entering the Raspberry Pi install the GPIO pin package into python by typing:

\$ sudo, apt-get install python-rpi.gpio

Picture 10. Coding for install package pin GPIO 
3. The next step is to create a new file called blynk with the python extension .py by typing the command:

\section{\$ sudo nano blink. py}

Picture 11. Coding to rename blynk

4. After the blink.py file opens next we will fill the file with the complete code as follows:

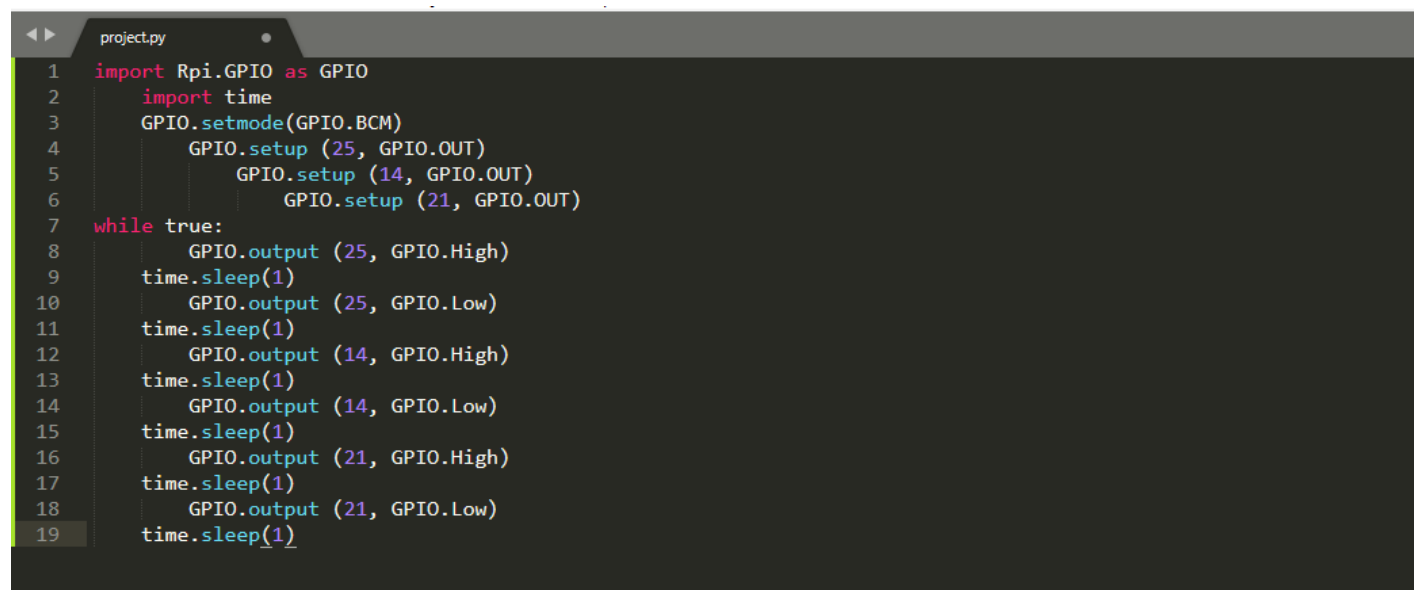

Picture 12. Coding To Turn On Traffic Led

5. The code has been completed and now we just save it with the command " $C+X$ " and the program steps have been completed.

6. The next step is to arrange the series of electronic components.

7. And see the results the LED will flicker and we have succeeded in making led blinking through raspberry pi and python, hopefully this tutorial is useful.

\subsection{Module RCWL- 0516}

To be able to communicate between the microcomputer and the Wi-Fi module and connected with the Blynk application using a special library that was added to Raspberry Pi 3B, namely Blynk application and ESP8266 module. This library functions to connect with Blynk application servers that communicate via the internet with the ESP8266 module.

\subsection{Remote Monitoring the Application}

Device monitoring and remote control of cell phones via a Wi-Fi network which is done using the application. This application can be used to control hardware remotely, display sensor data, store data, and has many features that can make it easier for users to use it. Blynk is an application designed for the Internet of Things (IoT). 


\subsection{Measurement by Object Movement}

The results of measuring some of the motions of objects are displayed. The data generated by the output of the RCWL 0516 sensor on the Blynk application has a difference of 1 second.

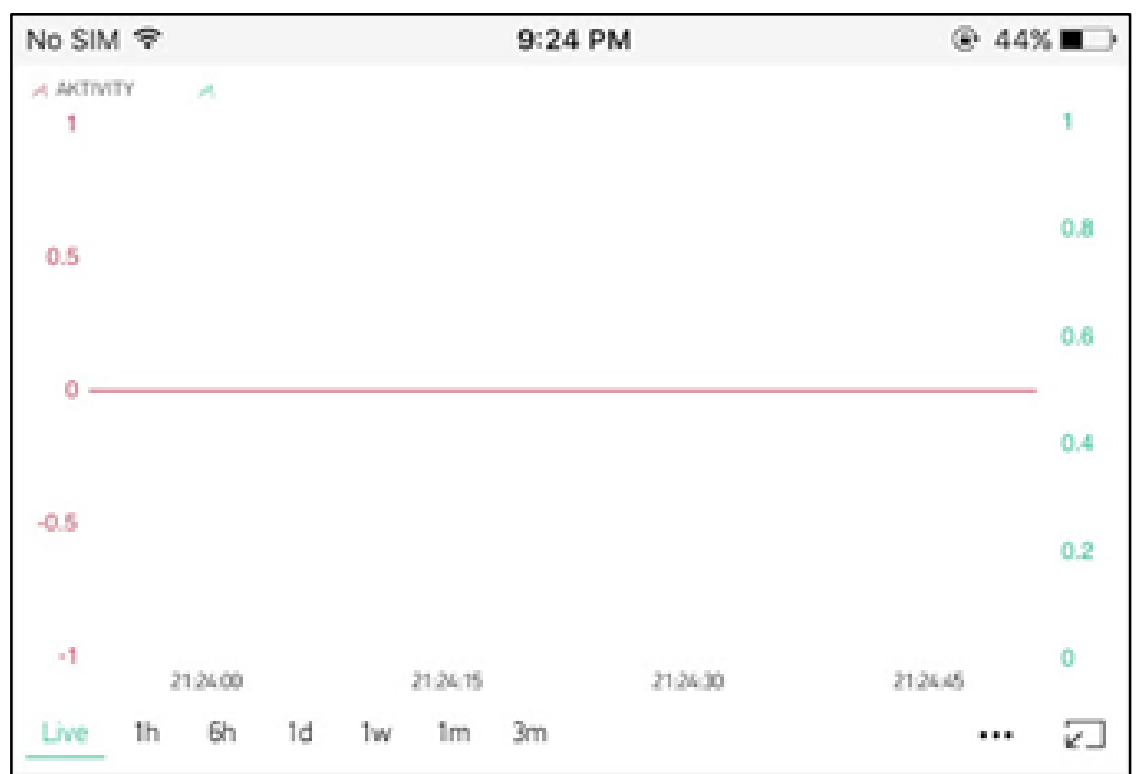

Picture 13. The graphic has no movement

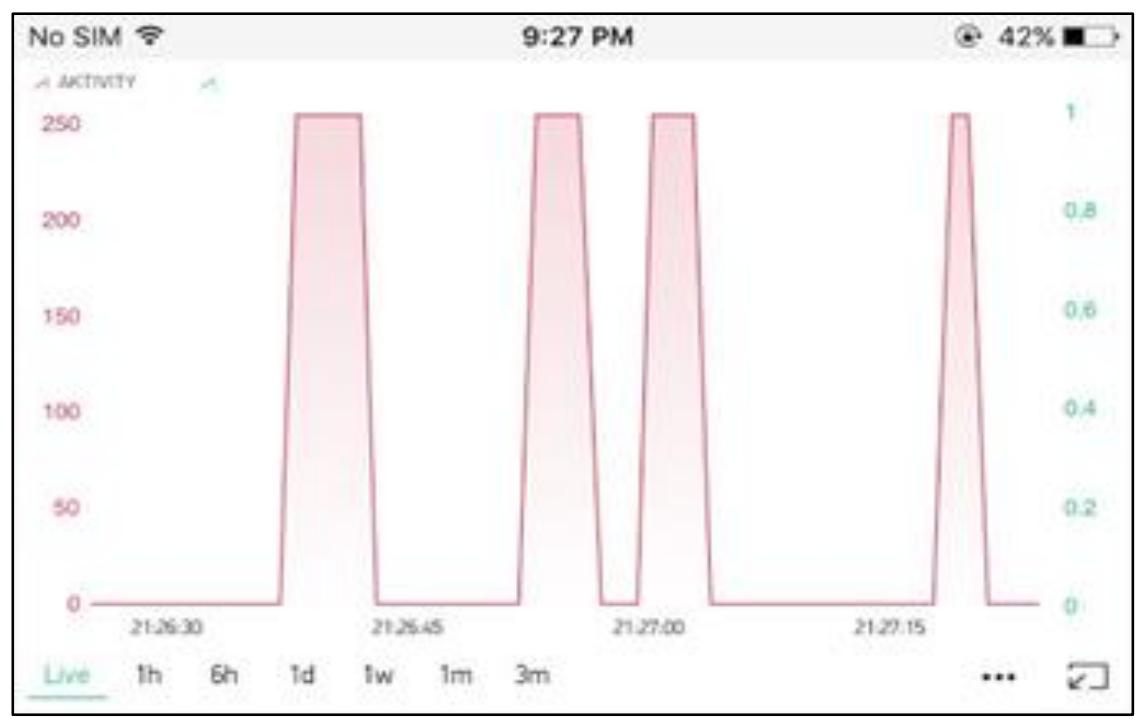

Picture 14. Rare movement graphic 


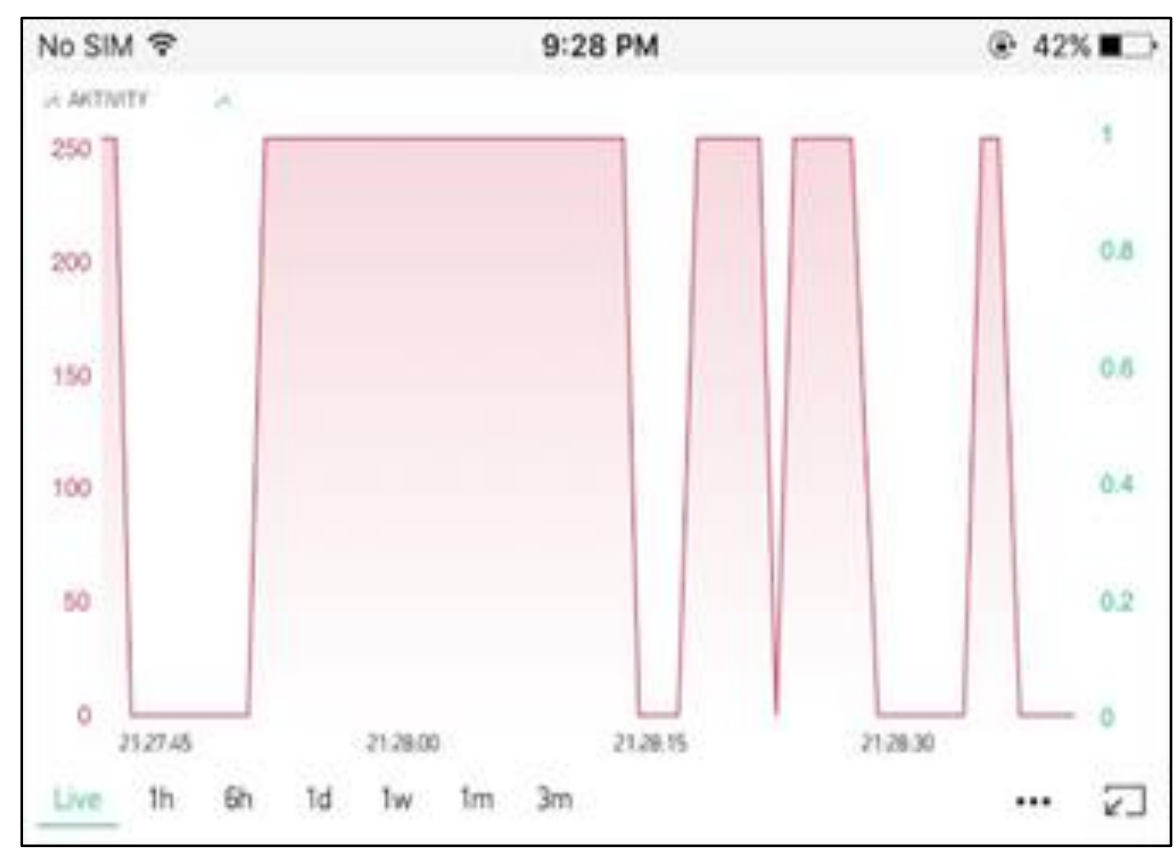

Picture 15. Graphic of frequent movements

\section{CONCLUSION}

Based on the result that have been done, according to the conclusions of the researchers are as follows:

1) This tool can be accessed by several users who have access in a fairly long distance.

2) This tool can help the user in monitoring the effectiveness of vehicle volume to reduce congestion at crossroads outside the work area.

3) This tool can send data on the movement of objects or humans in a room or place where the data is based on the volume of vehicles that occur in the field.

\section{SUGGESTED}

Based on the results of the research described above, the authors conclude 3 (three) suggestions for further development, including:

1) This tool can be developed in terms of design and components that can be used, which in the future is expected to improve the quality of the Raspberry Pi.

2) Need to add temporary electricity or backup energy in the event of a power outage. Where with the backup energy is expected to further improve the effectiveness of performance in reducing congestion.

3) Can be developed at the implementation stage by using more sensors as well as functions that can be further developed from various sides. 


\section{REFERENCES}

[1] Avian, C. PERANCANGAN MONITORING AND CONTROLLING TRAFFIC LIGHT PADA DIFFERENT STREET CONDITION MENGGUNAKAN JARINGAN INTERNET.

[2] Katadata, Jumlah Penduduk yang Tercatat di Negara Indonesia, https://databoks.katadata.co.id/datapublish/2018/05/18/2018-jumlah-pendudukindonesia-mencapai-265-juta-jiwa, diakses pada tanggal 16 Mei 2019.

[3] Wordpress, Fenomena Lalu Lintas, https://andri0204.wordpress.com/2013/02/07/fenomena-lalu-lintas-di-indonesia/ diakses pada tanggal 18 Mei 2019.

[4] Setiawan, P. R., Setiawan, F. A., Alam, S., \& Sulistiyanti, S. R. Rancang Bangun Model Deteksi Pelanggaran Zebra Cross Pada Traffic Light Menggunakan Metode Adaptive Background Subtraction.

[5] Aryani, D., Iskandar, D., \& Indriyani, F. (2018). PERANCANGAN SMART DOOR LOCK MENGGUNAKAN VOICE RECOGNITION BERBASIS RASPBERRY PI 3. CERITA Journal, 4(2), 180-189.

[6] Arafat, A. 2016. SISTEM PENGAMANAN PINTU RUMAH BERBASIS Internet Of Things (IoT) Dengan ESP8266. Jurnal Ilmiah TechnologiA, 7(4).

[7] Silvia, A. F., Haritman, E., \& Mulyadi, Y. (2014). Rancang Bangun Akses Kontrol Pintu Gerbang Berbasis Arduino Dan Android. Electrans, 13(1), 1-10.

[8] Prihatmoko, D. (2016). Perancangan dan implementasi pengontrol suhu ruangan berbasis mikrokontroler arduino uno. Simetris: Jurnal Teknik Mesin, Elektro dan Ilmu Komputer, 7(1), 117-122.

[9] Ratnawati, R., \& Silma, S. (2017). Sistem Kendali Penyiram Tanaman Menggunakan Propeller Berbasis Internet Of Things. Jurnal Inspiration, 7(2).

[10] Juwariyah, T., Prayitno, S., \& Mardhiyya, A. (2018). Perancangan Sistem Deteksi Dini Pencegah Kebakaran Rumah Berbasis Esp8266 dan Blynk. Jurnal Transistor Elektro dan Informatika (TRANSISTOR EI), 3(2), 120-126.

[11] Putra, D. M. PROTOTYPE SISTEM KONTROL DAN MONITORING KELEMBABAN TANAH MELALUI BLYNK SERVER LOCAL BERBASIS ANDROID.

[12] Imaniar, D., \& Juliansah, R. A. (2015). Sistem kontrol robot pemindah barang menggunakan aplikasi android berbasis Arduino Uno. CCIT Journal, 8(2), 45-56.

[13] Azhari, A., \& Soeharwinto, S. (2015). Perancangan Sistem Informasi Debit Air Berbasis Arduino Uno. Singuda Ensikom, 13(36), 89-95.

[14] Rahardja, U., Aini, Q., Apriani, D., \& Khoirunisa, A. (2019). Optimalisasi Informasi Manajemen Laporan Assignment Pada Website Berbasis Content Management System. Technomedia Journal, 3(2), 213-223.

[15] Kusumah, H., Indrianto, I., \& Pradana, O. A. (2019). Perancangan Smart Car Menggunakan Speech Recognition Berbasis Arduino Uno. SISFOTENIKA, 9(1), 59-70.

[16] Kurnianto, D., Hadi, A. M., \& Wahyudi, E. (2016). Perancangan Sistem Kendali Otomatis Pada Smart Home Menggunakan Modul Arduino Uno. Jurnal Nasional Teknik Elektro, 5(2), 260-270.

[17] Wikipedia, Raspberry $\mathrm{Pi}$, https://id.wikipedia.org/wiki/Raspberry_Pi, diakses pada tanggal 11 Mei 2019. 
[18] Wordpress, Kelebihan dan Kekurangan Raspberry Pi, https://risqiaf.wordpress.com/2017/12/30/kelebihan-dan-kekurangan-raspberry/ diakses pada tanggal 11 Mei 2019.

[19] Wikipedia, ESP8266, https://en.wikipedia.org/wiki/ESP8266, diakses tanggal $11 \mathrm{Mei}$ 2020.

[20] Blynk 2016: Docs, http://docs.blynk.cc/, 11 Mei 2020. 